\title{
Effect of Supplementary Methionine on Feather Growth and Related Indicators of Pigeon \\ Squabs
}

http://dx.doi.org/10.1590/1806-9061-2021-1468

Original Article

-Author(s)

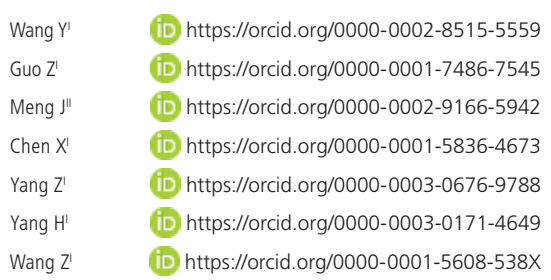

Wang Z

College of Animal Science and Technology, Yangzhou University, Yangzhou, Jiangsu Province, 225009, P. R. China.

" Changzhou Institute of Integrated Special Poultry, Changzhou, Jiangsu Province, P.R. China, 213163

\section{ABSTRACT}

We assessed the effect of health sand dietary supplementation with methionine (Met) on White King pigeons. Paired pigeons $(n=180)$ were fed one of five diets; group T1 received no added Met, while T2, T3, $\mathrm{T} 4$ and T5 received 30,60, 90 and $120 \mathrm{~g}$ of supplemental DL-Met/kg, respectively. Each treatment was replicated three times with 24 pairs in each replicate. The results showed that supplementary Met had a minor effect on the length of the fourth primary wing feather in 28-dayold squabs ( $p>0.05$ ), but the length of 14-day-old squabs in T2 was significantly longer $(p=0.010)$. Dietary Met had a minor effect on Wnt-7a and fibroblast growth factor receptors-2 (FGFR-2) mRNA levels in 28-dayold squabs ( $p>0.05)$. The IGF-1 concentration in plasma was highest in T4 and lowest in T2 ( $p=0.012)$, but there was no difference between T1, T2 and T5 ( $p>0.05)$. In the chest muscle, the expression of IGF-1 in T3 and T4 was higher than in T1 ( $p=0.172$ and 0.015 , respectively). In the leg muscle, IGF-1 mRNA level was higher in T4 and T3, and lower in T2 ( $p>0.05$ ). The results indicate that the optimal Met supplement for increasing fourth primary wing feather length was $30 \mathrm{~g} / \mathrm{kg}$ Met in health sand, and the feathers were the longest in 14-day-old squabs. Adding $90 \mathrm{~g} / \mathrm{kg}$ Met to health sand can improve the concentration of IGF-1, which is important for growth performance of pigeon squabs.

\section{INTRODUCTION}

In recent years, the White King pigeon has been a source of meat and eggs in human diet (Pomianowski et al., 2009). Pigeon meat is easily digestible, richer in protein, also considered as medicine in China (Kabir et al., 2013), and squabs are important for meat production (Sales \& Janssens, 2003). Methionine (Met) is considered a major growth-limiting amino acid in poultry (Bunchasak, 2009), and an important nutrient for feather growth and protein synthesis. Met deficiency impairs growth and metabolism, while excess met can be toxic (Harper et al., 1970). Met deficiency could impair the growth of broilers (Wu et al., 2012), Met supplemented to the diets positively affected body weight gain, feed conversion and production index of broilers (Koreleski \& Świątkiewicz, 2008). Feather growth is important for pigeons because it reflects carcass quality; optimum feathering is crucial in poultry production, and poor feathering results in downgrading of birds at slaughter (Hickling et al., 1900; Zeng et al., 2015). The width of the daily growth of the feathers has been used to assess the nutritional condition of the birds while the feathers were growing (Mallet-Rodrigues, 2012). Furthermore, Zeng et al. (2015) also revealed that dietary Met content can affect the feather growth in Peking duck; the optimal Met requirement for the fourth primary wing feather length was $0.404 \%$. However, studies on the optimal dosage of Met for feather growth in pigeons has not been reported. 
Feathers are epithelial appendages resulting from cell proliferation, cell differentiation and cell migration (Chuong \& Edelman, 1985). The size of the feather tracts can be altered by experimental modulation of Wnt pathway members. Wnts are secreted signalling molecules involved in the axis determination in vertebrates (Moon et al., 1997). The fibroblast growth factor (FGF) family of peptide growth factors is involved in cell proliferation and morphogenesis. FGF signals are mediated by high-affinity fibroblast growth factor receptors (FGFRs) (Matovinovic \& Richman, 1997). The spacing of feather buds involves signals from the epidermis to the underlying mesenchyme, including Wnt-7a and FGFs (Wolpert, 1998), and feather growth is closely related to Wnts and FGFRs. Noji et al. (1993) pointed out that Wnt7-a and FGFR-2 are expressed in the posterior domain of feather buds (Choung et al., 1990).

In the present study, we measured the length of the fourth primary wing feather in pigeon squabs, examined Wnt-7 and FGFR-2 mRNA levels in feathers, and determined growth indices including IGF-1 concentration in plasma and IGF-1 expression in chest and leg muscles, after supplementary Met was added to health sand.

\section{MATERIALS AND METHODS}

\section{Animals and management}

A total of 180 paired White King pigeons (180 males and 180 females) were obtained from the Tangshan Cuigu pigeon industry (Nanjing, China), and each pair fed two squabs (d1). Squabs with similar body weight $(16.78 \pm 2.15 \mathrm{~g})$ were divided into five groups, with six replicates in each group, and 12 pigeon squabs per replicate. Dietary treatment 1 (T1) contained no added Met, whereas treatments T2, T3, T4 and T5 contained $30 \mathrm{~g}, 60 \mathrm{~g}, 90 \mathrm{~g}$ and $120 \mathrm{~g}$ of supplemental DL-Met/ $\mathrm{kg}$ in health sand, respectively (Table 1). All groups were fed the same basal diet (Table 2), the health sand was fed separately, and water and food were available ad libitum. The birds were housed in pairs and raised under natural illumination over 31 days. The pigeons were raised in accordance with local farming practices.

\section{Feather growth}

At $\mathrm{d} 14$ and 28, 6 squabs per treatment were randomly selected for the analysis of feather growth, measuring the length of the fourth primary wing feather. The fourth primary wing feather length was measured using a ruler with a minimum scale of 0.01 $\mathrm{mm}$.
Table 1 - Composition and nutrient levels of the health sand (\%).

\begin{tabular}{lc}
\hline Ingredients & Content \\
\hline CaHPO $_{4}$ & 17 \\
Shell meal & 17 \\
Medium coarse sand & 38 \\
$\mathrm{NaCl}$ & 5 \\
\hline Premix & 17 \\
Strong complement vitamin & 20 \\
Cod-liver oil $^{3}$ & 2 \\
Total & 1 \\
\hline Nutrient levels & 100 \\
Ca & \\
TP5 & 10.84 \\
Lys & 3.87 \\
\hline
\end{tabular}

'Premix provided the following per kg of health sand: vitamin $A, 250000 \mathrm{IU}$; vitamin $\mathrm{D}_{3}, 82500 \mathrm{IU}$; vitamin $\mathrm{E}, 300 \mathrm{IU}$; vitamin $\mathrm{K}_{1} 40 \mathrm{mg}$; vitamin $\mathrm{B}_{1}, 20 \mathrm{mg}$; vitamin $\mathrm{B}_{2}, 170$ mg; pantothenic acid calcium, 1000 mg; nicotinic acid, 650 mg; vitamin $B_{6}, 160$ mg; vitamin $B_{12}, 100$ mg; biotin, 40 mg; Fe, 1200 mg; Cu, 160 mg; Zn, 66 mg; Mn, 1320 $\mathrm{mg}$; Se, $6 \mathrm{mg}$; I, $20 \mathrm{mg}$.

${ }^{2}$ Strong complement vitamin provided the following per $\mathrm{kg}$ of health sand: vitamin $\mathrm{A}$, $640000 \mathrm{IU}$; vitamin $\mathrm{D}_{3}, 60000 \mathrm{IU}$; vitamin E, $130 \mathrm{lU}$; vitamin $\mathrm{K}_{3}, 50 \mathrm{mg}$; vitamin $\mathrm{B}_{1}$, 30 mg; vitamin $B_{2}, 60$ mg; pantothenic acid calcium, 300 mg; nicotinic acid, 700 mg; vitamin $B_{6}, 40$ mg; vitamin $B_{12}, 0.1 \mathrm{mg}$.

${ }^{3}$ Cod-liver oil provided the following per $\mathrm{kg}$ of health sand: vitamin A, $300000 \mathrm{IU}$; vitamin $\mathrm{D}_{3}, 30000 \mathrm{IU}$; vitamin E, $300 \mathrm{IU}$; vitamin C, $1 \mathrm{~g}$.

${ }^{4}$ Nutrient levels were calculated value.

${ }^{5}$ Total phosphorus.

Table 2 - Composition and nutrient levels of the basal diet (air-dry basis) (\%).

\begin{tabular}{lc}
\hline Ingredients & Content \\
\hline Corn grain & 57.9 \\
\hline Soybean meal & 35 \\
Wheat bran & 7.1 \\
\hline Total & 100 \\
\hline Calculated nutrient ${ }^{1}$ & \\
\hline Metabolizable energy (MJ/kg) & 12.69 \\
Crude Protein (\%) & 14.77 \\
Calcium(\%) & 0.06 \\
Phosphorus (\%) & 0.27 \\
\hline Lysine (\%) & 0.62 \\
Methionine (\% & 0.40 \\
\hline
\end{tabular}

'Nutrient levels were calculated value.

\section{Tissue collection}

In total, 30 birds (on d28) were selected randomly from the five groups (six squabs from each group) and the feather pulp was isolated from the fourth primary wing feather. Chest and leg muscles were collected at the same time of day, immediately frozen in liquid nitrogen, and stored at $-80^{\circ} \mathrm{C}$ until analysis. Nine squabs from each group were selected and blood samples ( 0.5 to $0.8 \mathrm{~mL}$ per sample) were collected from 0900 to $1000 \mathrm{~h}$. Blood was collected, immediately transferred to tubes containing $2 \mu \mathrm{L}$ heparin sodium $(0.8 \mathrm{M})$, and 
centrifuged at $3000 \times g$ for $5 \mathrm{~min}$ at $4^{\circ} \mathrm{C}$. Plasma samples were stored at $-20^{\circ} \mathrm{C}$ until further analysis.

\section{Plasma IGF-1 concentration assay}

The concentration of IGF-1 in plasma was measured using a commercial ELISA kit (Nanjing Jiancheng Co. Ltd., Nanjing, China) according to the manufacturer's protocol. Each sample was measured in triplicate, and concentrations are represented as $\mathrm{ng} / \mathrm{mL}$ in plasma. The lowest limit of detection was $3 \mathrm{ng} / \mathrm{mL}$. Intra-assay and inter-assay coefficients of variation were lower than $10.0 \%$ and $12.0 \%$, respectively.

\section{Real-time PCR (RT-PCR) analysis}

Total RNA was extracted using Trizol reagent (Invitrogen, USA) following the manufacturer's protocol and reverse transcribed using a Fast Quant RT Kit (catalogue numbers DP405 and KR106, respectively; TIANGEN Biotech Co., LTD, Beijing, China). Expressions of IGF-1, Wnt-7a and FGFR-2 were measured by RT-PCR using primers designed based on the coding region of the target genes (Table 3). SuperReal PreMix (SYBR Green; catalogue number FP204; TIANGEN Biotech Co., Ltd.) was used to detect expression. Reactions $(20 \mu \mathrm{L})$ contained $10 \mu \mathrm{L} 2 \times$ SuperReal Premix, $0.4 \mu \mathrm{L}$ $50 \times$ ROX Reference Dye, $0.6 \mu \mathrm{L}$ of each primer, $1 \mu \mathrm{L}$

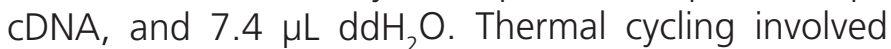
CDNA denaturation at $95^{\circ} \mathrm{C}$ for $15 \mathrm{~min}$, followed by 40 cycles at $95^{\circ} \mathrm{C}$ for $10 \mathrm{~s}$ and $60^{\circ} \mathrm{C}$ for $32 \mathrm{~s}$. Assays were repeated independently three times.
Table 3 - Primer sequences of target genes and GAPDH gene.

\begin{tabular}{llc}
\hline Gene & Sequence (5'- 3') & Length (bp) \\
\hline \multirow{2}{*}{ GAPDH } & $\begin{array}{l}\text { F:CTCTACTCATGGCCACTTCCG } \\
\text { R:ACAACGTATTCAGCACCAGC }\end{array}$ & 138 \\
Wnt-7a & $\begin{array}{l}\text { F:TCCCAGAAGAAACGCTGACGA } \\
\text { R:GTCAGTGCTGCTTGCTTAACCA }\end{array}$ & 172 \\
FGFR-2 & $\begin{array}{l}\text { F:TGCCTTCACAGAGACCGAC } \\
\text { R:TCATCACCTGAAGAACACGAG }\end{array}$ \\
IGF-1 & $\begin{array}{l}\text { F:ATGGCACATTCATTCTTCGTT } \\
\text { R:CACCTAAATCTGCACGCTCT }\end{array}$ & 157 \\
\hline
\end{tabular}

\section{Statistical analysis}

Data are expressed as means \pm standard error and analysis was performed by one-way ANOVA using SPSS 13.0 (SPSS Inc., Chicago, IL, USA). The significance of differences between groups was evaluated by the least significant difference post hoc multiple comparisons test. The significance level was set at $p<0.05$.

\section{RESULTS}

\section{Feather growth}

The effect of dietary Met supplementation on feather growth of squabs is presented in Table 4. Although the length of the fourth primary wing feather of 28-dayold squabs supplemented with dietary Met was longer than the control treatment, there were no betweentreatment differences $(p=0.973)$. Compared with the control treatment, the fourth primary wing feather length of 14-day-old squabs in T2 was significantly

Table 4 - Feather growth of squabs fed varying concentrations of dietary Met at $14 d$ and $28 d$ age.

\begin{tabular}{ccccccc}
\hline Item & T1 & T2 & T3 & T4 & T5 & SEM \\
\hline $14 \mathrm{~d}$ & $52.49^{\mathrm{a}}$ & $56.19^{\mathrm{b}}$ & $52.14^{\mathrm{a}}$ & $52.58^{\mathrm{a}}$ & $48.99^{\mathrm{c}}$ & 0.98 \\
28d & 129.16 & 129.78 & 129.39 & 129.64 & 129.43 & 1.18 \\
\hline
\end{tabular}

Values marked with different lower letters in row are significantly different $(p<0.05)$, different capital letters in row are very significantly different $(p<0.01)$.

longer than T5 $(p=0.010)$. However, with increasing supplemental dosage, the fourth primary wing feather of squabs decreased, and T5 had the shortest length $(p<0.001)$. These results suggested that dietary Met supplementation had no effect on the fourth primary wing feather length of 28-day-old squabs, however, it affected the feather length of squabs aged 14 days.

\section{Analysis of Wnt-7a and FGFR-2 expression}

The effects of dietary Met on the expression of Wnt-7a and FGFR-2 were examined by RT-PCR (Fig. 1). Expression of Wnt-7a was highest in T4 and lowest in $T 5$, but there were no differences between these treatments $(p>0.05)$. FGFR-2 mRNA levels were higher in T4 than in other groups, but there were no differences among different treatments ( $p>0.05)$. Thus, dietary Met had a minor effect on Wnt-7a and FGFR-2 mRNA levels, which related to the feather growth.

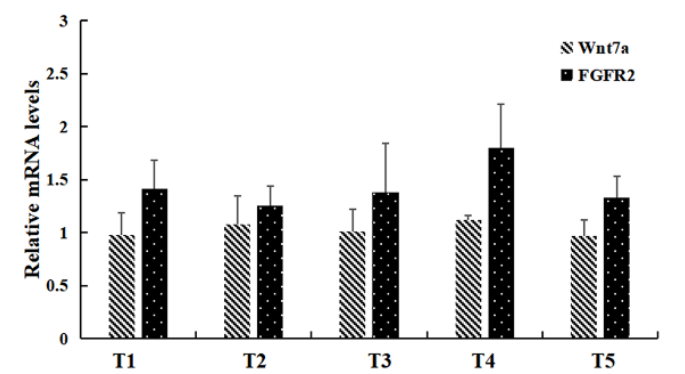

Figure 1 - The expressions of Wnt-7a and FGFR-2 in feathers under different dietary Met. Values marked with different letters on the bars are significantly different $(p<0.05)$.

\section{IGF-1 concentration in plasma}

Determination of the IGF-1 concentration in plasma (Table 5) showed that it was highest in T4 and lowest in 
Table $\mathbf{5}$ - The concentration of IGF-1 of squabs fed varying concentrations of dietary Met ( $\mathrm{ng} / \mathrm{mL})$.

\begin{tabular}{lcccccc}
\hline Item & T1 & T2 & T3 & T4 & T5 & SEM \\
\hline IGF-1 & $42.06^{\mathrm{a}}$ & $41.67^{\mathrm{a}}$ & $54.07^{\mathrm{b}}$ & $56.70^{\mathrm{b}}$ & $48.07^{\mathrm{a}}$ & 2.82 \\
\hline
\end{tabular}

Values marked with different lower letters in row are significantly different $(p<0.05)$.

T2 $(p=0.012)$, but there were no differences between $\mathrm{T} 1, \mathrm{~T} 2$ and T5 $(p>0.05)$. Although the concentration of IGF-1 was higher in T4 than in T3, there was no difference $(p=0.963)$, which indicated that the concentration of dietary Met in T4 and T3 increased the IGF-1 concentration.

\section{Analysis of IGF-1 expression in chest and leg muscle}

Expression of IGF-1 in the chest and leg muscle of squabs under different dietary Met treatments is shown in Fig. 2. In the chest muscle, IGF-1 mRNA level was higher in T4 than in T3, but there was no significant difference $(p=0.101)$. Expression of $/ G F-$ 1 in T1 was lower than in T3 and T4 ( $p=0.172$ and 0.015 , respectively), but there were no differences among T1, T2 and T5 ( $p>0.05)$. In the leg muscle, IGF1 mRNA levels were higher in T4 and T3, and lower in $\mathrm{T} 2$, but there were no differences among different treatments $(p>0.05)$. The results indicated that dietary Met affected the expression of IGF-1 in the chest and leg muscles.

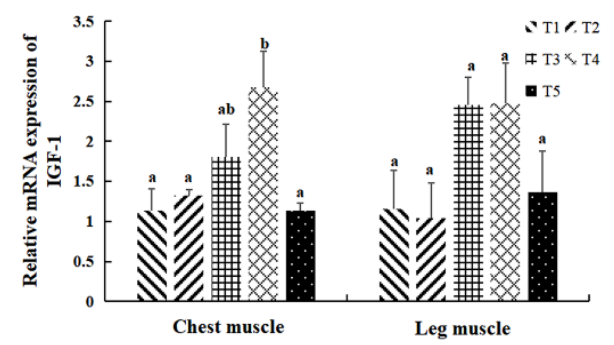

Figure 2 - The expressions of IGF-1 in chest muscle and leg muscle under different dietary Met. Values marked with different letters on the bars are significantly different $(p<0.05)$.

\section{DISCUSSION}

The NRC (1994) recommendation for Met in the diet of chickens is $0.5 \%$ at 21 days and $0.38 \%$ at 42 days. In the present study, the fourth primary wing feather length was significantly longer in pigeon squabs supplied with $30 \mathrm{~g} / \mathrm{kg}$ Met in health sand than in other treatments at 14 days of age, and there was a significant decrease in birds receiving $120 \mathrm{~g} / \mathrm{kg}$ Met, which is in accordance with Agostini et al. (2016), who suggested that a lower Met requirement in the starter phase should be administered. Our results indicate that supplementary Met affects feather growth in starter (day 1 to 14) pigeon squabs, and adding $30 \mathrm{~g} /$ $\mathrm{kg}$ Met to health sand can induce feather growth, Guo (2011) also found that supplementary Met in 1 to 21 $d$ of age Pekin duck's diet increased feather growth. Although feather growth was greater in the $30 \mathrm{~g} / \mathrm{kg}$ Met treatment than in the other treatments at 28 days of age, there were no differences among different treatments. Zhang et al. (2014) indicated that a deficiency of Met can lead to impaired feather growth of Pekin ducks, which suggested that adequate Met didn't affect feather growth. Furthermore, UrdanetaRincon \& Leeson (2004) demonstrated that feather growth of broilers from 1 to $21 \mathrm{~d}$ of age were more influenced by dietary CP per se than by levels of animo acid.

In this study, we measured mRNA levels of FGFR2 and Wnt-7a, since FGFs are known to induce new feather buds (Jung et al., 1998), and Wnt-7a is involved in anterior-posterior patterning (Hammerschmidt \& McMahon, 1997). Widelitz et al. (1999) demonstrated that overexpression of Wnt-7a caused feather buds to stop elongating and to become plateau-shaped appendages. FGFR-2 is expressed in the feather placode epithelium (Orr-Urtreger et al., 1991), and overexpression of FGFR-2 in the skin of chicken embryos results in the complete failure of feather formation (Mandler \& Neubüser, 2004). Wnt-7a and FGFR-2 play key roles in feather growth in birds. In the present work, although the expressions of Wnt-7a and FGFR-2 at 28 days of age was in accordance with the rhythm of feather growth, adding Met had little effect on expressions of these genes, which may be related to the fact that the primary wing feather has already completed growth, furthermore, squabs were sold in the market at the age of 28 days. Met supplement may be effective at the growing period of squabs.

The expression of IGF-1 in chest muscle was higher in the $90 \mathrm{~g} / \mathrm{kg}$ Met treatment, but there were no differences between treatments in the leg muscle in our study. However, Del Vesco et al. (2013) previously reported higher levels of IGF-I mRNA in the liver of broilers receiving Met supplementation, while IGF-I expression in the muscle tissue was not affected. The concentration of IGF-1 in plasma was also higher in the $90 \mathrm{~g} / \mathrm{kg}$ Met treatment, in accordance with Takenaka et al. (2000). Carew et al. (2003) suggested that the 
IGF-1 concentration was affected by restriction of Met and the level of Met deficiency. Chickens with a high growth rate display higher circulating levels of IGF-1 (Beccavin et al., 2001), and Guernec et al. (2003) reported that /GF-I mRNA levels are important in muscle growth rate during development. IGF-1 can be used as an indicator of growth rate in birds. Thus, our results suggest that supplementing $90 \mathrm{~g} / \mathrm{kg}$ Met in health sand improved the growth performance of pigeon squabs. Feather growth is also an important aspect of the growth performance of squabs. Thus, further studies are needed to explore the molecular mechanism by which supplementary Met impacts feather growth in starter (day 1 to 14) and grower (day 15 to 28 ) pigeon squabs.

In conclusion, in 14-day-old squabs, the optimal Met supplement level for feather growth was $30 \mathrm{~g} / \mathrm{kg}$ Met in health sand, but this had little effect on 28-dayold squabs. Additionally, adding $90 \mathrm{~g} / \mathrm{kg}$ Met to health sand can improve the content of IGF-1 in pigeon squabs, which may improve the growth performance of pigeons.

\section{ACKNOWLEDGMENTS}

This study was funded by Jiangsu Modern Agricultural Industrial Technology System, Nanjing Jiangning Cuigu Promotion Demonstration Base (JATS [2019] 017), Jiangsu Overseas Visiting Scholar Program for University Prominent Young and Middle-aged Teachers and Presidents and the Priority Academic Program Development of Jiangsu Higher Education Institutions (PAPD; Jiangsu, China).

\section{AUTHORSHIP CONTRIBUTION STATEMENT}

Ying Wang, Haiming Yang and Zhiyue Wang contributed to the overall design of the study. Ying Wang, and Jun Meng collected data. Ying Wang, Zhenyu Guo, Xiaoshuai Chen and Zhengfeng Yang contributed to sample collection. Ying Wang participated in the manuscript writing and revision. All authors approved the final version of the manuscript.

\section{COMPETING INTERESTS}

The authors declare no conflict of interest. The fundings had no role in the design, execution, interpretation, or writing of the study.

\section{REFERENCES}

Agostini PS, Dalibard P, Mercier Y, Van der Aar P, Van der Klis JD. Comparison of methionine sources around requirement levels using a methionine efficacy method in 0 to 28 day old broilers. Poultry Science 2016;95:560-569.

Beccavin C, Chevalier B, Cogburn LA, Simon J, Duclos MJ. Insulin-like growth factors and body growth in chickens divergently selected for high or low growth rate. The Journal of Endocrinology 2001;168:297306 .

Bunchasak C. Role of dietary methionine in poultry production. Journal of Poultry Science 2009;46:169-179.

Carew LB, McMurtry JP, Alster FA. Effects of methionine deficiencies on plasma levels of thyroid hormones, insulin-like growth factors-I and-II, liver and body weights, and feed intake in growing chickens. Poultry Science 2003;82:1932-1938.

Chuong CM, Edelman GM. Expression of cell-adhesion molecules in embryonic induction. I. Morphogenesis of nestling feathers. The Journal of Cell Biology 1985;101:1009-1026.

Chuong CM, Oliver G, Ting SA, Jegalian BG, Chen HM, De Robertis EM. Gradients of homeoproteins in developing feather buds. Development 1990;110:1021-1030.

Del Vesco AP, Gasparino E, Oliveira Neto AR, Guimarães SE, Marcato SM, Voltolini DM. Dietary methionine effects on IGF-I and GHR mRNA expression in broilers. Genetic Molecular Research 2013;12:64146423.

Guernec A, Berri C, Chevalier B, Wacrenier-Cere N, Le Bihan-Duval E, Duclos MJ. Muscle development, insulin-like growth factor-I and myostatin mRNA levels in chickens selected for increased breast muscle yield. Growth hormone \& IGF research 2003;13:8-18.

Guo F. Effects of methionine on feather development of started Peking ducks of 0 to $21 \mathrm{~d}$ of age [dissertation]. Beijing (CN): The Chinese Academy of Agricultural Sciences; 2011.

Hammerschmidt M, Brook A, McMahon AP. The world according to bedgebog. Trends in Genetics 1997;13:14-21.

Harper AE, Benevenga NJ, Wohlhueter RM. Effects of ingestion of disproportionate amounts of amino acids. Physiological Reviews 1970;50:428-558.

Hickling D, Guenter W, Jackson ME. The effects of dietary methionine and lysine on broiler chicken performance and breast meat yield. Canadian Journal of Animal Science 1990;70:673-678.

Jung HS, Francis West PH, Widelitz RB, Jiang TX, TingBerreth SA, Tickle $C$, et al. Local inhibitory action of BMPs and their relationships with activators in feather formation:implications for periodic patterning. Developmental Biology 1998;196:11-23.

Kabir MA. Productivity of crossed indigenous pigeon in semi intensive system. Basic Research Journal of Agricultural Science and Review 2013;2:1-4

Koreleski J, Świątkiewicz S. Effect of protein and methionine levels in a semi-organic diet for dual-purpose type chickens on slaughter performance and nitrogen balance. Journal of Animal and Feed Sciences 2008;17:381-391.

Mallet-Rodrigues F. Replacement and growth of primary feathers in captive Rock Pigeons, Columba livia (Aves: Columbidae). Zoologia 2012;29:121-125. 
Mandler M, Neubüser A. FGF signaling is required for initiation of feather placode development. Development 2004;131:3333-3343.

Matovinovic E, Richman JM. Epithelium is required for maintaining FGFR-2 expression levels in facial mesenchyme of the developing chick embryo. Developmental Dynamics 1997;210:407-416.

Moon R T, Brown J D, Torres M. WNTs modulate cell fate and behavior during vertebrate development. Trends in Genetics 1997;13:157-162.

Noji S, Koyama E, Myokai F, Nohno T, Ohuchi H, Nishikawa K, et al. Differential expression of three chick FGF receptor genes, FGFR1, FGFR2 and FGFR3, in limb and feather development. Progress in Clinical and Biological Research 1993;383:645-654.

NRC. Nutrient requirements of poultry. $9^{\text {th }}$ rev. ed. Washington: Natl. Acad. Press; 1994.

Orr-Urtreger A, Givol D, Yayo An, Yarden Y, Lonai P. Developmental expression of two murine fibroblast growth factor receptors, flg and bek. Development 1991;113:1419-1434.

Pomianowski JF, Mikulski D, Pudyszak K, Cooper RG, Angowski M, Jozwik $A$, et al. Chemical composition, cholesterol content, and fatty acid profile of pigeon meat as influenced by meat-type breeds. Poultry Science 2009;88:1306-1309.

Sales J, Janssens GPJ. Nutrition of the domestic pigeon (Columba livia domestica). World's Poultry Science Journal 2003;59:221-232.

Takenaka A, Oki N, Takahashi S, Noguchi T. Dietary restriction of single essential amino acids reduces plasma insulin-like growth factor-1 (IGF1) but does not affect plasma IGF-binding protein-1 in rats. The Journal of Nutrition 2000;130:2910-2914.
Urdaneta-Rincon M, Leeson S. Effect of dietary crude protein and lysine on feather growth in chicks to twenty-one days of age. Poultry Science 2004;83:1713-1717.

Widelitz RB, Jiang TX, Chen CW, Stott NS, Chuong CM. Wnt-7a in feather morphogenesis:involvement of anterior-posterior asymmetry and proximal-distal elongation demonstrated with an in vitro reconstitution model. Development 1999;126:2577-2587.

Wolpert L. Pattern formation in epithelial development:the vertebrate limb and feather bud spacing. Philosophical transactions of the Royal Society of London 1998;353:871-875.

Wu BY, Cui HM, Xi P, Jing F, Wei C, Liu XD. Effect of methionine deficiency on the thymus and the subsets and proliferation of peripheral blood T-cell, and serum IL-2 contents in broilers. Journal of Integrative Agriculture 2012;11:1009-1019.

Zeng QF, Zhang Q, Chen X, Doster A, Murdoch R, Makagon M, et al. Effect of dietary methionine content on growth performance, carcass traits, and feather growth of Pekin duck from 15 to 35 days of age. Poultry Science 2015:94:1592-1599.

Zhang Q, Xu L, Doster A, Murdoch R, Cotter P, Gardner A, et al. Dietary threonine requirement of Pekin ducks from 15 to 35 days of age based on performance, yield, serum natural antibodies, and intestinal mucin secretion. Poultry Science 2014;93:1972-1980. 